This is an electronic reprint of the original article. This reprint may differ from the original in pagination and typographic detail.

Author(s): Shaikh, Aijaz A.; Glavee-Geo, Richard; Karjaluoto, Heikki

Title: How relevant are risk perceptions, effort, and performance expectancy in mobile banking adoption?

Year: $\quad 2018$

Version:

Please cite the original version:

Shaikh, A. A., Glavee-Geo, R., \& Karjaluoto, H. (2018). How relevant are risk perceptions, effort, and performance expectancy in mobile banking adoption?. International Journal of E-Business Research, 14(2), Article 39-60. https://doi.org/10.4018/IJEBR.2018040103

All material supplied via JYX is protected by copyright and other intellectual property rights, and duplication or sale of all or part of any of the repository collections is not permitted, except that material may be duplicated by you for your research use or educational purposes in electronic or print form. You must obtain permission for any other use. Electronic or print copies may not be offered, whether for sale or otherwise to anyone who is not an authorised user. 


\title{
How Relevant Are Risk Perceptions, Effort, and Performance Expectancy in Mobile Banking Adoption?
}

\author{
Aijaz A. Shaikh, University of Jyväskylä, Jyväskylä, Finland \\ Richard Glavee-Geo, NTNU-Norwegian University of Science and Technology, Norway \\ Heikki Karjaluoto, University of Jyväskylä, Jyväskylä, Finland
}

\begin{abstract}
This article provides a comprehensive overview of the adoption process using evidence from m-banking adoption in Pakistan. A survey design was used and 189 responses were received from across Pakistan and analyzed using Smart PLS application. Findings suggest that research on the effect of risk in the adoption process remains inconclusive. Contrarily, consumers have overcome many fears due to the usefulness, indispensability, high security features, and effort expended in the use of financial services delivered through m-banking. Perceived risk's (PR) direct influence was found to be generally weak. However, PR plays a major role in the pre-adoption process because it's weak and direct inhibiting influence become an "enhancer" in the association between effort expectancy (EE) and the three key TAM/UTAUT constructs [performance expectancy (PE), attitude (ATT), and adoption intention (INT)]. Most importantly, the role of EE as a strong driver of PE, ATT, INT, and its significant interaction with PR highlights the unique role that both risk and EE play in the adoption process.
\end{abstract}

\section{KEYWORDS}

Attitude, Developing Country, Intention, Mobile Banking Adoption, Perceived Risk

\section{INTRODUCTION}

Mobile banking (m-banking) is defined as an innovative banking service offered to consumers by financial services firms, such as banks, credit unions, and microfinance institutions, for conducting various transactions via a portable device, such as a mobile phone, smartphone, or tablet anytime anywhere (Shaikh \& Karjaluoto, 2015). Despite the noted benefits of using mobile devices for banking purposes and conducting transactions remotely, the security of consumers' personal as well as banking information is paramount, and breaches of either create consumer skepticism, which lowers the adoption rate of m-banking services.

In addition, increasing security concerns and scares among consumers living in developing countries, which have fragile infrastructures, are becoming vexing challenges for banking institutions. Similarly, risks are generally considered to be higher when conducting transactions online and remotely 
using portable devices, which are prone to hacking, loss, and misuse. Therefore, customers who use these devices for banking are commonly reluctant to make payments and transfer funds on them because the risk may be high when compared to traditional (branch-oriented) banking. Considering this paradox, prior research (e.g., Alalwan et al., 2017; Masrek et al., 2014; Shaikh \& Karjaluoto, 2016a; Shen \& Chiou, 2010) has addressed the antecedent "Trust" and "perceived risk" (PR) as crucial factors in consumer behavior and purchase decisions, especially in the context of electronic commerce in general and digital banking in particular.

Against this backdrop, this study contributes to the ongoing debate on m-banking adoption antecedents and examines the effects of perceived risk, effort expectancy and performance expectancy on consumer behavior when accepting m-banking services in Pakistan. The research questions on which the objectives were evaluated were as follows: First, how does perceived risk affect consumers' intentions and attitudes when choosing to accept m-banking services? Second, how does perceived risk moderate the association between effort expectancy - performance expectancy, effort expectancy attitude, and effort expectancy - adoption intention link? Third, what are the roles of effort expectancy and performance expectancy in the pre-adoption stage of $\mathrm{m}$-banking services?

The findings of this study are encouraging for banking companies and non-banking institutions, such as mobile application developers, the telecom sector, and rapidly emerging FinTech start-ups. Moreover, this study offers valuable policy implications for government regulatory institutions, providing better insight into mobile-based banking services as well as the factors leading to acceptance. The article concludes with a series of recommendations for the development of m-banking as a tool to expand the access to financial services to a demographically disbursed population.

In the remaining sections, we will present the literature review followed by research model and hypotheses. Then we present the research methodology, and the results. A discussion of the study's findings, theoretical contributions, practical implications, limitations, and recommendations for future research will conclude this paper.

\section{LITERATURE REVIEW}

\section{Mobile Banking - Conceptualization and Definition}

Against the backdrop of growing digitization of banking delivery channels, especially during the 1990s, banks and other financial institutions started developing and providing multi-channel service delivery options so customers could better access banking information and conduct transactions. A multi-channel service delivery system integrates physical and virtual channels (Martin et al., 2014). The prominent physical banking channels include bank branches, ATMs, and POS terminals, while virtual banking channels include the Internet and mobile devices.

The extensive usage of portable devices such as cell phones for banking and payments has popularized the usage of $\mathrm{m}$-banking services in several countries, expanded access to formal banking transactions in emerging and developing countries (Shaikh \& Karjaluoto, 2016b), transformed the financial services distribution models, reduced transactional costs, and improved the quality of life of the consumers. With regard to emerging and developing markets, m-banking has expanded the distribution and delivery channels for financial services (Oliveira et al., 2014) among underbanked and unbanked consumers.

Several definitions have been proposed for $\mathrm{m}$-banking. For example, considering m-banking as an important e-business tool and e-commerce application, Mehrad \& Mohammadi (2016) defined m-banking as a mobile commerce application that enables customers to bank at virtually any time and place. Boor et al. (2014) considered m-banking as a natural evolution of electronic banking that empowers consumers to complete financial transactions via mobile or handheld devices. Figure 1 illustrates the retail digital banking options available to consumers. 


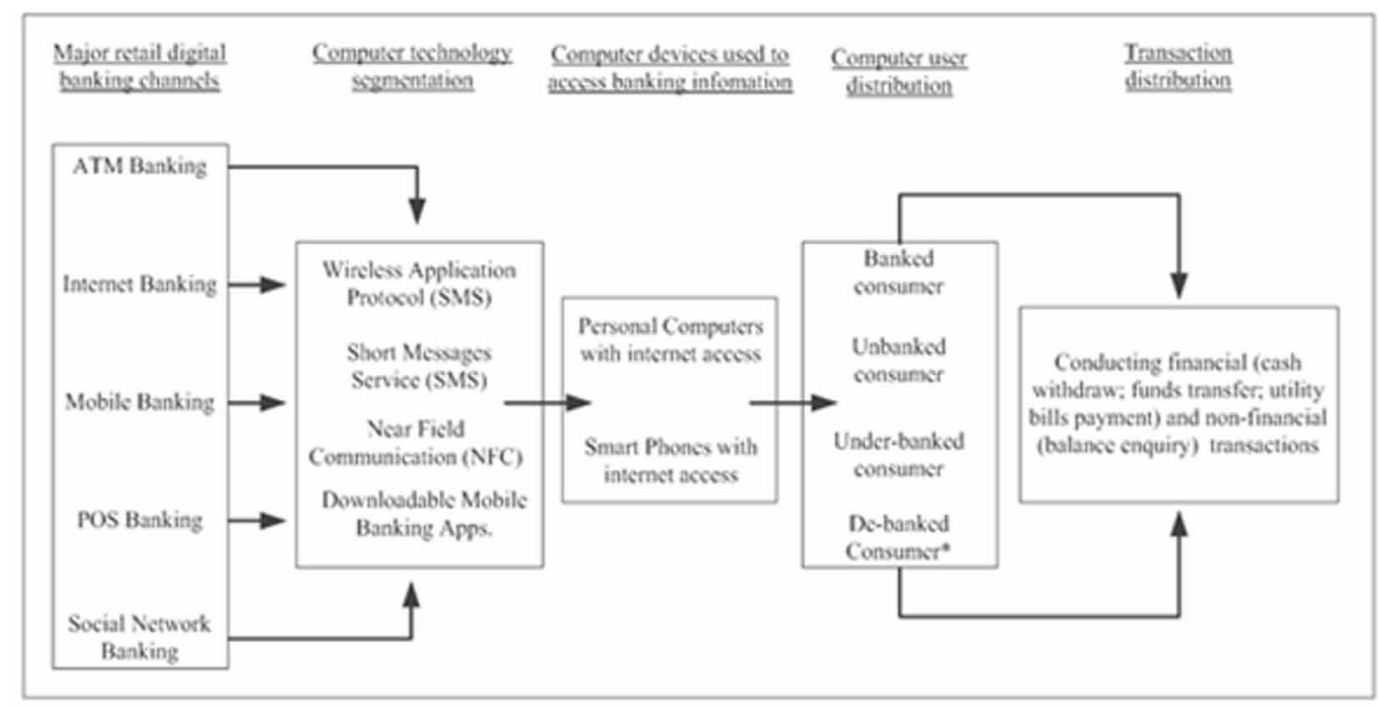

- De-barked are those consumers who despite being provided with branch nework, ATMS, bie Internet, and ATM, prefor not to have a bank account. They prefer to use innovative products and services, largely prepaid in nature. Unlike underbarked and unbanked consuner segment, de-banked consuners and highty aw are, and tech-sany conswners.

Unlike other digital banking channels, such as ATMs, m-banking provides seamless convenience and offers anytime, anywhere services. The scope of these services includes customer-centric conventional banking services, payment services, and recently, value-added services. According to Chawla et al. (2017), banking services include, text or SMS banking, and also downloadable m-banking apps. Payment services include utility bill payments and funds transfers. Value-added services include virtual or mobile wallets, cross-selling and marketing, personal financial management, and remote or virtual support. These innovative services have turned cell phones and tablets into business tools, replacing traditional bank branches, ATMs, and payment cards by allowing users to conduct financial transactions remotely at any time (Varshney \& Vetter, 2001).

\section{Perceived Risk and Technology/Innovation Adoption Models}

In 1975, the Theory of Reasoned Action (TRA) was developed and proposed by Fishben and Ajzan (1975). TRA was initially used in social psychology research. A decade later in 1985, Ajzen (1985) proposed the Theory of Planned Behaviour (TPB). These two theories were primarily developed to focus on individual perceptions as the primary drivers of pre-adoption intention and behavior. Later, two information technology-specific variants of TRA and TBP were developed: the Technology Acceptance Model (TAM) and the Unified Theory of Acceptance and Usage of Technology (UTAUT) (Shaikh, 2016; Bhattacherjee \& Sanford, 2006). TAM, developed by Davis (1989), was specifically developed to explain and predict end-user computer and information systems (e.g., m-banking) initial adoption behavior and consists of two important beliefs or antecedents: perceived usefulness and perceived ease of use. An extension to TAM, UTAUT was proposed by Venkatesh et al. (2003), integrating four factors: performance expectancy (similar to perceived usefulness), effort expectancy (similar to perceived ease of use), social influence (similar to social or subjective norm), and facilitating conditions (similar to perceived behavioral control). Unlike TAM, UTAUT has not been widely used, but it was recently applied for exploring user acceptance of mobile technologies (Zhou et al., 2010). Considering the close association and interdependence of these adoption models, this research 
integrates the UTAUT, TPB, and perceived risk to examine the user acceptance or pre-adoption of m-banking services (see Figure 2).

The two independent variables, performance expectancy and effort expectancy, are the primary components of UTAUT. Two additional variables, attitude and adoption intention, were taken from TPB. In addition, the antecedent perceived risk has been used as a moderator that affects the direct relationship between effort expectancy $\rightarrow$ performance expectancy, effort expectancy $\rightarrow$ attitude, and effort expectancy $\rightarrow$ adoption intention.

Perceived risk is defined as a negative consequence that arises from the purchase of a new product or service, such as m-banking (Karjaluoto et al., 2014). In the marketing and information systems literature, perceived risk has been studied and used since the early 1960s; similarly, considerable research has examined the impact of risk on traditional consumer decision-making processes (e.g., Karjaluoto et al., 2014; Lee, 2009; Lin, 2008). Internet banking and m-banking services are prone to similar risks (Luo et al., 2010). Lee (2009) examined a host of antecedents that influence the adoption of internet banking in Taiwan and found that the intention to use online banking is negatively affected by security, privacy, and financial risks. Considering the close relationship of the Internet (or online) and $\mathrm{m}$-banking, it is assumed that perceived risk that influences usage attitude and intention will also be applicable in the context of m-banking. Nonetheless, Karjaluoto et al. (2014) found a negative relationship between perceived risk and attitude (Akturan \& Tezcan, 2012; Kuo \& Yen, 2009) and intention to adopt mobile technology (Thakur \& Srivastava, 2014), especially in the technology acceptance context. In sum, prior research has considered perceived risk as an independent variable, but its treatment as a moderator in the context of m-banking has rarely been examined.

Perceived risk is considered important in online banking and payment services (Chen, 2013), and in developing countries, which have fragile telecommunications networks, the security concerns are even more intriguing. In such circumstances, the consumer-perceived risk is important when deciding whether to acquire or adopt a new technology or services such as m-banking (Sylvie \& Xiaoyan, 2005).

Figure 2. Effort expectancy-perceived risk contingency model

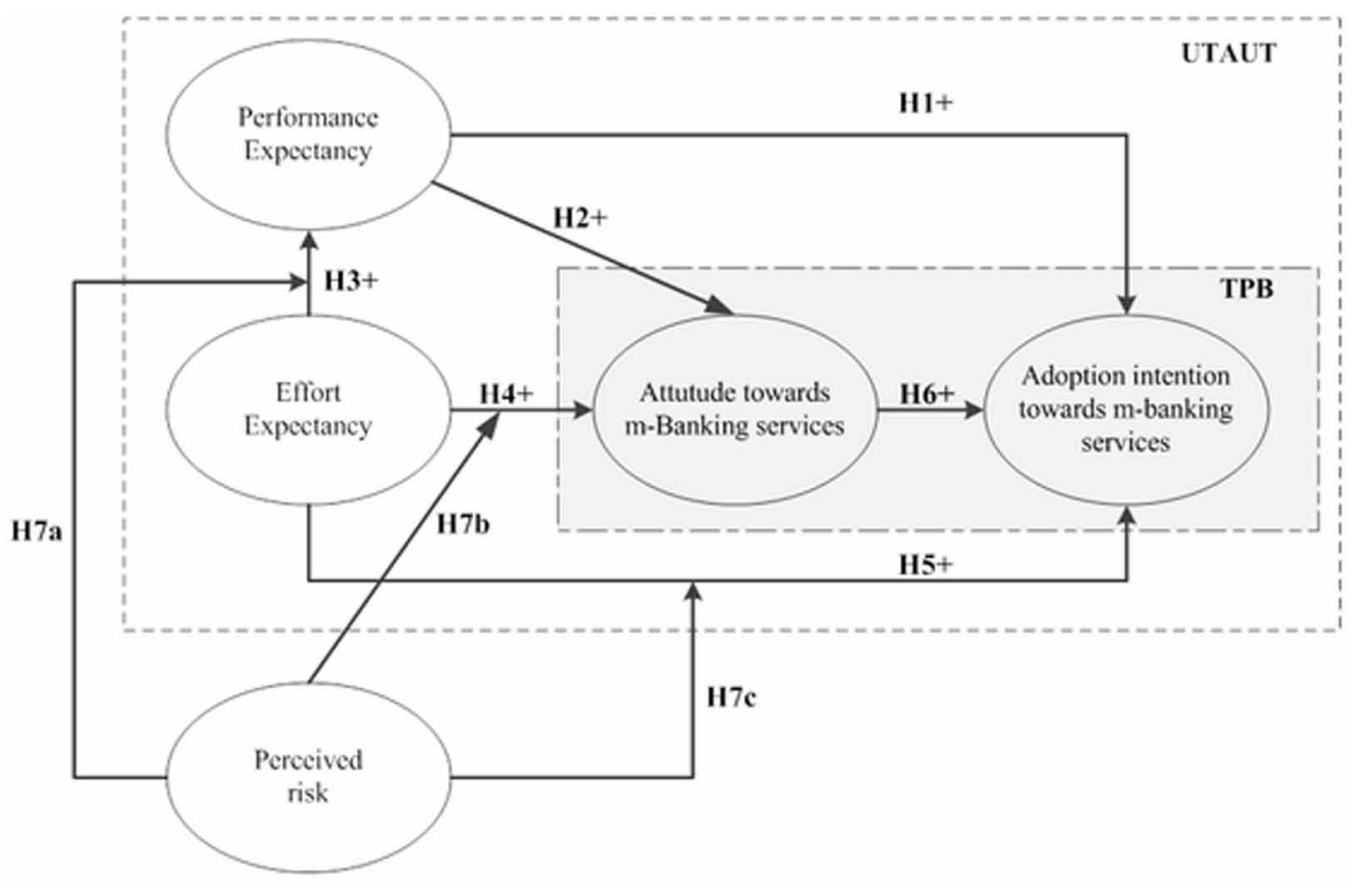




\section{RESEARCH MODEL AND HYPOTHESES}

To investigate the effects of perceived risk (PR), performance expectation, and effort expectation, on both consumer attitude (ATT) and adoption intention (INT), we developed and proposed a research model, as illustrated in Figure 2. In line with our theoretical basis, this research model includes five constructs and nine hypotheses. The main endogenous variables in our study include ATT and INT. The model suggests that both performance expectancy (PE) and effort expectancy (EE) have positive effects on ATT and INT, whereas PR is negatively related to both endogenous variables-ATT and INT (though not explicitly shown in Figure 2). EE is suggested to have a positive effect on PE. Furthermore, ATT is hypothesized to be positively related to INT. Finally, the authors considered the moderating effect of PR. First, the rationale for modeling perceived risk as a moderator between the two key UTAUT constructs (i.e. EE and PE) and between EE and the two key TPB constructs (ATT and INT) is to fill the gap in the literature where previous research had overlooked this interrelationships between UTAUT, TPB and risk (see Table 1). The second is to provide alternative explanatory rationale for the contingent effect that perceived risk is likely to play between the key UTAUT constructs and with it and TPB constructs. By so doing we are able to provide an increased understanding of the adoption process models through the lens of the key constructs of UTAUT and TPB in predicting technology and innovation adoption at various levels of risk perception.

\section{Performance Expectancy, Consumer Attitude, and Adoption Intention}

Research (e.g., Venkatesh et al., 2003) has defined antecedent "performance expectancy" as the degree to which consumer believes that using an information system, such as m-banking, will help attain gains in job performance. Prior studies (Luo et al., 2010; Oliveira et al., 2014; Riffai et al., 2012) have found that PE is a vital antecedent in consumers' acceptance of m-banking technology;

Table 1. Summary of prior research examining "perceived risk" in the context of m-banking services adoption

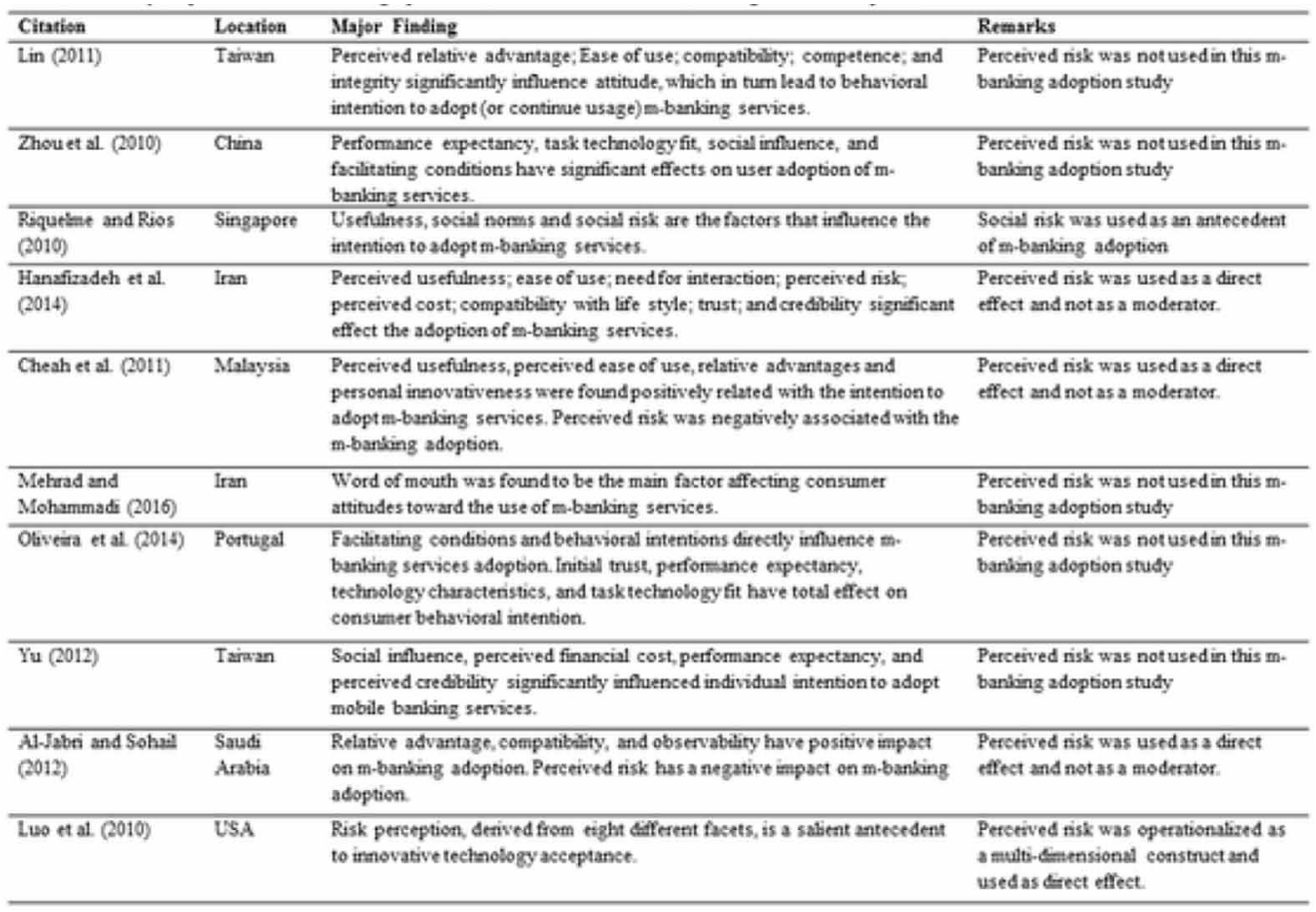


further, its direct relationships with both consumer ATT and INT toward m-banking services and applications have been established. For instance, Akturan \& Tezcan (2012) found that ATT is the major determinant of m-banking adoption INT. Similarly, as argued by Oliveira et al. (2014), initial trust, PE, technology characteristics, and task technology fit directly affect consumer behavioral INT in $\mathrm{m}$-banking services adoption. Against this backdrop, it is believed that, as with perceived usefulness, the PE of $\mathrm{m}$-banking is expected to have a positive impact on both ATT and INT behaviors (Crabbe et al., 2009). The following were therefore hypothesized:

H1: PE of m-banking services positively influences adoption INT.

H2: PE of m-banking services positively influences consumer ATT.

\section{Effort Expectancy and Performance Expectancy}

The effort expectancy (perceived ease) of m-banking services has a direct relationship with the performance expectancy (perceived usefulness). This relationship infers that increased ease of $m$-banking services will increase the usefulness or rather the perceived utility of m-banking systems and vice versa. Previous studies have generally supported this hypothesis, i.e., perceived ease of use can strengthen perceived usefulness (Davis, 1989; Kuo \& Yen, 2009). Luarn and Lin (2005) concluded that perceived ease of use influences perceived usefulness in the m-banking context.

Specifically, the Unified Theory of Acceptance and Usage of Technology (UTAUT), which was developed by Venkatesh et al. (2003), proposed a direct relationship between EE and PE and suggested that EE positively affects PE, i.e., when both potential and existing consumers feel that m-banking is easy to access and easy to use, they will have high expectations regarding acquiring the expected performance. By integrating the task technology fit model and the UTAUT, Zhou et al. (2010) proposed an m-banking user adoption model and found that EE strongly affects PE. Thus, the following was hypothesized:

H3: EE of m-banking services positively influences the PE of m-banking services.

\section{Effort Expectancy, Consumer Attitude, and Adoption Intention}

Similar to the antecedent PE, it is proposed that the antecedent "effort expectancy" has a direct relationship with consumer ATT, which implies that increasing EE (the perceived ease associated with m-banking services) will develop a positive consumer ATT toward m-banking services and vice versa. Lack of EE in using $\mathrm{m}$-banking services will reduce user satisfaction and, in some cases, the consumer may discard m-banking adoption if the service providers, including banks, cannot present an easy-to-use m-banking interface to potential consumers. These arguments are intriguing in the case of developing countries, such as Pakistan, which have high illiteracy rates and a minute understanding of technology and innovation.

Prior research (i.e., Shaikh, 2016; Venkatesh et al., 2003) has defined the antecedent "effort expectancy" as the degree of ease associated with the use of an information system. Similar to PE, prior research (e.g., Akturan \& Tezcan, 2012) has found that EE directly affects ATTs toward m-banking, and ATT is the major determinant of m-banking adoption INT. Against the backdrop of these arguments, the following were hypothesized:

H4: EE of m-banking services positively influences consumer ATT.

H5: EE of m-banking services positively influences adoption INT.

\section{Consumer Attitude and Adoption Intention}

Research has used the construct "attitude" to measure the INT of an individual to perform a particular behavior (Ahmed et al., 2013). Especially in the context of mobile technology and 3G mobile value- 
added services, Teo and Pok (2003) and Kuo and Yen (2009) have provided clear evidence that the relationship between ATT and behavioral INT is supported and significant. While identifying the critical antecedents of wireless application protocol services adoption in Taiwan, Hung et al. (2003) found significant links between ATT and INT. Extending the same argument in the context of $\mathrm{m}$-banking services, if $\mathrm{m}$-banking services provide information that is quick, easy, and readily available, the user may develop a more favorable ATT (Pillai \& Mitra, 2016), thereby increasing adoption INT toward m-banking services. Therefore, the following was hypothesized:

H6: Consumer ATT positively influences consumer adoption INT.

\section{The Moderating Effects of Perceived Risk}

In addition to using the PR as an antecedent of adoption INT and EE, the authors developed three hypotheses that analyzed the moderating effect of PR on the relationship between the following: EE and PE (H7a); $\mathrm{EE}$ and consumer ATT (H7b); and EE and consumer adoption (H7c). The moderating effect of PR has not been widely examined in the prior literature; however, some studies do support our hypotheses.

$\mathrm{H} 7$ a suggests that, at high levels of PR, EE has a stronger positive association with PE. Hence, risk perceptions do not pose much of a threat to consumers in the pre-adoption stage due to m-banking services' ease of use and perceived usefulness. Im et al. (2008) argued that PR changes the effects of $\mathrm{PE}$ and $\mathrm{EE}$ on behavioral INT. In other words, consumers who perceive a higher risk when adopting a technology, such as m-banking, will be affected by how easy it can be used. For example, when banks deploy a technology that is perceived by consumers as risky, they need to emphasize its ease of use (Im et al., 2008) to develop a positive ATT toward that technology and thus increase adoption rates.

$\mathrm{H} 7 \mathrm{~b}$ describes how, at high levels of PR, EE (perceived ease of use) regarding accessing and using m-banking services has a stronger positive association with ATT. Hence, risk perceptions do not pose much of a threat to consumers in the pre-adoption stage due to m-banking services' ease of use and consumers' favorable attitudes toward them.

$\mathrm{H} 7 \mathrm{c}$ demonstrates that, at high levels of PR, EE has a stronger positive association with adoption INT. In other words, risk perceptions do not pose much of a threat to consumers in the pre-adoption stage due to m-banking services' ease of use and consumers' intent to adopt the services. Considering the close association between Internet and m-banking, Shen and Chiou (2010) examined the moderating effect of PR on the perceived ease of use (effort expectancy) of Internet service adoption and argued that the perceived ease of use of a website will affect consumers' intentions, despite an increasing PR. In the context of web-based technology, similar findings were also shared by Im et al. (2008), who found PR to be a significant moderating variable and thus concluded that the moderating effect of PR on the relationship between effort expectancy / perceived ease of use and INT are significant. Therefore, we hypothesized the following:

H7a: PR moderates the relationship between EE and PE such that, in conditions of high PR, EE has a stronger positive association with PE.

H7b: PR moderates the relationship between EE and consumer ATT such that, in conditions of high PR, EE has a stronger positive association with consumer ATT.

H7c: PR moderates the relationship between EE and consumers' adoption INT such that, in conditions of high PR, EE has a stronger positive association with adoption INT.

\section{RESEARCH METHODOLOGY}

\section{Survey Instrument, Measurement, and Pilot Study}

Each of the variables included in the research model was measured with items on a scale, where one represents 'strongly disagree' to seven represents 'strongly agree'. The items that measured the 
five latent variables were therefore drawn from previously validated instruments. The three and four items that measured INT and ATT, respectively, were adopted from a study by Cheng et al. (2006). $\mathrm{EE}$ and PE were measured with six and four items, respectively, which were adopted from Zhou et al. (2010). PR was measured with four items, which were taken from a study by Karjaluoto et al. (2014). The wording of the items was modified from the original sources whenever possible for our research context, i.e., m-banking. The items, their means, standard deviations, and loadings are listed in Table 2.

A pilot study was conducted to pre-test both the data and the survey instrument with a sample of master degree students at a local business institute in Sukkur city. Although it is widely believed that a pilot study does not guarantee success in the main study, it greatly increases the probability (Simon, 2011) of the responses. The feedback received from the pre-test participants was collated and included where necessary to improve clarity, validate the reliability of the items (Kim et al., 2009), increase the comprehensibility of the instructions, improve the wording of the items, and determine if the items were yielding the kind of information that was needed (Simon, 2011).

\section{Data Collection and Assessment of Non-Response Bias}

The data were collected from Pakistan using a purposeful sampling technique, in which the survey participants were selected according to the needs and requirements of the study (Shaikh \& Karjaluoto, 2016a). For example, all those who owned a cell phone and had been using it for the previous six months were considered and included in this survey. The data were collected using an online tool (the modified data instrument was uploaded online using the Webropol application) and on-site data collection methodology during an eight-week period that began in August 2014 (from 8/20/2014 to $10 / 18 / 2014$ ). The data source consists of 189 respondents. Following the standard criterion, we assess the nonresponse bias by comparing the first $25 \%$ of survey respondents to the last $25 \%$. Here we did not find any significant difference between the two groups ( $p>0.05$ level), which shows that nonresponse bias was not a problem.

\section{Assessment of Common Method Bias}

Common method bias (CMV) is a variance that is attributable to the measurement method rather than the constructs (Podsakoff et al., 2003). The data for all the model variables came from the same respondents at the same time; therefore, CMV might have influenced some of the hypothesized

Table 2. Construct indicators and loadings ( $n$ "189)

\begin{tabular}{|c|c|c|c|c|}
\hline Construct/source & Indicators & $\mathrm{M}$ & SD & Loadings \\
\hline Adeption intention & I would ust an-banking for my banking aetds (DT1). & 5.62 & 1223 & $09240 \%$ \\
\hline \multirow[t]{2}{*}{ Cheng ef al (2006). } & Using m-barving for handling my banking transactions is something I would $d o$ (DNT2). & 5.62 & 1.109 & $0933 \% 00$ \\
\hline & I can see myself usingm-banking for handing my banking transactions (DNT3). & 5.74 & 1244 & $0.923 * * *$ \\
\hline Attitude & Using m-baniking would be a good bad idea (ATT1). & 5.50 & 1.198 & $0.855 * 40$ \\
\hline \multirow[t]{3}{*}{ Cheng at al (2006). } & Using m-banising would be a foolish wise idea (ATT2). & 5.12 & 1.629 & $0.750 * * *$ \\
\hline & I distike tike the idea of using m-banking (ATT3). & 5.48 & 1.457 & $0.856 \% * 0$ \\
\hline & Using m-baniving would be ungleasant pleasant (ATT4). & 5.47 & 1.335 & $0.874 * * *$ \\
\hline Effort Expectancy & Leaming to operate mbanking would be easy for me (EEI). & 5.48 & 1.340 & $0.832^{* * *}$ \\
\hline \multirow[t]{5}{*}{ Zhou et al (2010) } & I would find it easy to get m-banking to do what I want it to do (EE2). & 5.35 & 1232 & $0.835 * \ldots$ \\
\hline & My interaction with m-banking would be clear and understandable (EE3). & 5.31 & 1.350 & $0.874 * \cdots$ \\
\hline & I would find $m$-banking to be flevible to interact with (EE 4 ). & 5.31 & 1.310 & $0.877 * *$. \\
\hline & It would be easy for me to become slalled at using m-banting (EES). & 5.57 & $12 m$ & $0.862 * * *$ \\
\hline & I would find m-banking easy to use (EE6). & 5.47 & 1295 & $0.814 * * *$ \\
\hline \multirow{5}{*}{$\begin{array}{l}\text { Perceived risk } \\
\text { Karjaluoto et at. } \\
\text { (2014). }\end{array}$} & The decision of whether to use mbanking services is nisky (PRI). & 353 & 1.664 & $0.950 \cdots$ \\
\hline & Using m-banking services puts my privacy at risk (PR2). Reversed. & 3.23 & 1.576 & $0.814 \cdots$ \\
\hline & Compared with other banking channels, such as the intemet, $m$-banking has more uncertainties & 3.60 & 1.641 & $0.616 \cdots$ \\
\hline & (PR3). & 3.42 & 1.687 & $0.836 * *$ \\
\hline & In general, 1 believe using an m-banking service is risky (PRA). & & & \\
\hline \multirow{4}{*}{$\begin{array}{l}\text { Performance } \\
\text { expectancy } \\
\text { Zhou et al (2010) }\end{array}$} & I think that using m-banking would enable me to accomplish my tasks mere quickly (PE1). & 5.65 & 1.485 & $0.871^{\cdots *}$ \\
\hline & I think that using m-banking would make it easier for me to carry out my tasks (PE2). & 5.53 & 1.371 & $0.894 * \ldots$ \\
\hline & I think m-banking is useful (PE3). & 5.83 & 1.274 & $0.843 * \cdots$ \\
\hline & Overall, I think using $=$-banking is advantageous (PEA). & 5.76 & 1235 & $0.841 * *$ \\
\hline
\end{tabular}


relationships in the structural model (Chang et al., 2010; Podsakoff et al., 2003). The common method bias procedure involves a series of steps. First, we used single-factor statistical control test (Harman,1976) to evaluate CMV. According to Podsakoff and Organ (1986), CMV is a problem if a single factor materializes from the unrotated factor solution. A one-factor solution accounted for only $19.8 \%(<50 \%)$ of the overall variance, which indicated that CMV bias was not likely to have affected the study's findings. However, this test has limitations (Kemery \& Dunlap, 1986).

In addition to the Harman's (1976), we modified the PLS model by linking a new second order factor (termed the method construct) to the first order factors. The reanalysis yielded an average factor loading of 0.70 and the average variance explained by the common method factor was 0.01 . This demonstrates that common method bias did not pose any serious issue to our study.

\section{RESULTS}

The study sample of 189 participants consisted of $61.4 \%$ males and $38.6 \%$ females. Around half of the respondents (50.8\%) had a bachelor qualification, and approximately one-third (61.4\%) were students. More than $70 \%$ of the respondents maintained a regular bank account. About half of the survey respondents $(41.3 \%$ ) had been using a cell phone for five years or more, while far fewer (2.6\%) had used a cell phone for less than one year. Demographic characteristics of the sample are presented in Table 3.

\section{Assessment of the Measurement Model}

The measurement model and the structural relationships were tested through partial least squares (PLS) using the SmartPLS 3.0 (Ringle et al., 2015). PLS was a more suitable statistical technique for the analysis due to a number of advantages: (1) its ability to simultaneously estimate complex

Table 3. Demographic characteristics of respondents ( $n$ "189)

\begin{tabular}{|c|c|c|c|}
\hline Demographic Characteristics & Category & Frequency & Percent \\
\hline \multicolumn{4}{|l|}{ Gendes } \\
\hline & Male & 116 & 61.4 \\
\hline & Female & 73 & 38.6 \\
\hline \multicolumn{4}{|l|}{ Age } \\
\hline & 15.25 & 97 & 51.3 \\
\hline & $26-30$ & 30 & 21.2 \\
\hline & $31-40$ & 19 & 10.0 \\
\hline & $41-50$ & 21 & 11.1 \\
\hline & $51-60$ & 9 & 4.8 \\
\hline & $\geq 61$ & 3 & 1.6 \\
\hline \multicolumn{4}{|l|}{ Highest level of education } \\
\hline & College & 40 & 21.2 \\
\hline & Batheles & 96 & 50.8 \\
\hline & Mastef & 53 & 28.0 \\
\hline \multicolumn{4}{|l|}{ Curreat employent status } \\
\hline & Student & 116 & 61.4 \\
\hline & Employed & 54 & 28.6 \\
\hline & Entrepreneur & 17 & 9.0 \\
\hline & Unemployed & 2 & 1.0 \\
\hline \multicolumn{4}{|l|}{$\begin{array}{l}\text { Cell phone usage expenience of } \\
\text { (no. of years) }\end{array}$} \\
\hline & $<1$ & 5 & 2.6 \\
\hline & $>1$ & 9 & 4.8 \\
\hline & $>2$ & 21 & 11.1 \\
\hline & $>3$ & 42 & 222 \\
\hline & $>4$ & 34 & 180 \\
\hline & $>5$ & 78 & 41.3 \\
\hline
\end{tabular}


models with multiple interaction effects, a large number of constructs and relationships; (2) it is less strict with assumptions about the distribution of the data, and (3) it is ideal for a small sample size (Barclay et al., 1995; Chin \& Newsted, 1999; Hair et al., 2017). Factor loadings of 0.5 or more are considered acceptable (Barclays et al., 1995). All factor loadings were greater than 0.7 except PR3 which had a loading of 0.616 , as shown in Table 2.

\section{Convergent and Discriminant Validity}

We assess scale reliability as well as convergent and discriminant validity according to Fornell and Larcker's (1981). The convergent validity was assessed by the average variance extracted (AVE), where a value of 0.5 indicates an acceptable level (Fornell \& Larcker, 1981). The AVE values ranged from 0.70 to 0.86 (see Table 4), and all were above the acceptable value of 0.5 . We also assess discriminant validity using Fornell and Larcker's (1981) criterion, which states that the square root of the AVE (diagonal values) should be greater than the correlations among any given pair of constructs (see Table 5).

\section{Assessment of the Structural Model}

We estimated and evaluated the structural model by performing bootstrapping in SmartPLS3 application. Tables 6 and 7 shows the results of the structural model.

H1 stated a positive association between PE and adoption INT. Results from the analysis of the dataset did support the positive association between PE and adoption INT $(\beta=0.11, p>0.05)$. H2, which stated a positive association between PE and ATT, was weakly supported $(\beta=0.15, \mathrm{p}<0.10$, one-tailed). EE effect on PE (H3: $\beta=0.66, p<0.001)$, ATT (H4: $\beta=0.38, p<0.001)$, and INT (H5: $\beta=0.33, p<0.001)$ were supported, respectively. PR was found to have a weak negative association with ATT $(\beta=-0.10, p<0.10)$ and insignificant association with INT $(\beta=-0.06, p>0.05)$. The effect of ATT on adoption INT was supported (H6: $\beta=0.34, \mathrm{p}<0.001)$, which is consistent with the theory of planned behavior (Ajzen, 1985; 1991) and the technology acceptance model (Davis, 1989). The study found EE to be a strong driver of the adoption process through its significant effect on PE,

Table 4. Composite reliability, Cronbach's alpha and average variance extracted (n"189)

\begin{tabular}{lccc}
\hline & Composite reliablity & Cronbach's Alpha & Average variance extracted (AVE) \\
\hline Adoption intention & 0.95 & 0.92 & 0.86 \\
Attitude & 0.90 & 0.86 & 0.70 \\
Effort expectancy & 0.94 & 0.92 & 0.72 \\
Perceived risk & 0.91 & 0.89 & 0.72 \\
Performance expectancy & 0.92 & 0.89 & 0.75 \\
\hline
\end{tabular}

Table 5. Discriminant validity coefficients (n"189)

\begin{tabular}{|c|c|c|c|c|c|c|c|c|c|c|}
\hline & 1 & 2 & 3 & 4 & 5 & 6 & 7 & 8 & 9 & 10 \\
\hline Aceount holser (1) & 1 & & & & & & & & & \\
\hline Age (2) & 0.20 & 1 & & & & & & & & \\
\hline Adoption intention (3) & -0.02 & 0.08 & 0.93 & & & & & & & \\
\hline Attitude (4) & -0.01 & -0.04 & 0.60 & 0.84 & & & & & & \\
\hline Usage espenitase (5) & 0.03 & -0.03 & 0.06 & 0.07 & 1 & & & & & \\
\hline Education (5) & 0.13 & 0.21 & 0.11 & 0.03 & 0.04 & 1 & & & & \\
\hline Effort expectassy (7) & $-0,02$ & 0.12 & 0,62 & 0.53 & 0.07 & 0.11 & 0.85 & & & \\
\hline Gender (\$) & 0.06 & 0.14 & .0 .05 & 0.09 & 0.01 & 0.03 & 0.01 & 1 & & \\
\hline Perceived riak (9) & 0.13 & -0.13 & -0.07 & -0.06 & 0.10 & 0.02 & 0.00 & -0.01 & 0.83 & \\
\hline Performunse expetuncy (10) & 0.01 & -0.03 & 0.55 & 0.50 & 0.06 & 0.17 & 0.70 & -0.01 & -0.04 & 0.86 \\
\hline
\end{tabular}

Bold numbers on the diagonal shows the square root of the AVE. Nueubers below the diagonal represent the construct correlation. 
Table 6. Path coefficients, effect size and VIF

\begin{tabular}{|c|c|c|c|c|c|}
\hline Criterion & Predictor & $\beta$ & t-vahuet & $\begin{array}{l}\text { Effect size } \\
\text { (f) }\end{array}$ & VIF \\
\hline Pefformance expectancy & Gender & .0 .05 & 0.96 & 0.01 & 1.04 \\
\hline \multirow[t]{7}{*}{$\mathrm{R}^{2}=0.55$} & Education & 0.13 & $285 * *$ & 0.04 & 1.07 \\
\hline & Usage experience & 0.00 & 0.01 & - & 1.02 \\
\hline & Age & -0.17 & $3.37 * 0.4$ & 0.06 & 1.16 \\
\hline & Account holder & 0.07 & $1.30^{*}$ & 0.01 & 1.10 \\
\hline & Effort expectancy & 0.65 & $1220 * * *$ & 0.89 & 1.09 \\
\hline & Percetived nisk & -0.10 & $1.57^{*}$ & 0,02 & 1.09 \\
\hline & Effort expectancy x Pefceived risk & 0.16 & $2.13 * *$ & 0.07 & 1.10 \\
\hline Effost expectancy & Gendet & 0,02 & 0.30 & - & 1.03 \\
\hline \multirow[t]{5}{*}{$\mathrm{R}^{2}=0,03$} & Education & 0,09 & $1.28^{*}$ & 0,01 & 1.06 \\
\hline & Usage expexience & 0.07 & 0.85 & $\cdot$ & 1.01 \\
\hline & Age & 0.12 & $1.55^{*}$ & 0,01 & 1.14 \\
\hline & Account holder & $-0,06$ & 0.80 & - & 1.08 \\
\hline & Perceived nisk: & 0,01 & 0.11 & - & 1.06 \\
\hline
\end{tabular}

Note: "Bated on 1000 bootstrapping samples; ENect stze of lest than 0.01 are not shown

${ }^{* *} p<0.001, " * p<0.05$ (two-failed), " $p<0.10$ (anc-tatled)

Table 7. Path coefficients, effect size and VIF

\begin{tabular}{|c|c|c|c|c|c|}
\hline Criterion & Predictor & $\beta$ & t-valueil & $\begin{array}{c}\text { Effect size } \\
\left(\mathrm{f}^{2}\right)\end{array}$ & VIF \\
\hline Attitude & Gender & 0.07 & $1.28^{*}$ & 0.01 & 1.04 \\
\hline \multirow[t]{8}{*}{$\mathbb{R}^{2}=0.38$} & Education & -0.02 & 0.34 & - & 1.11 \\
\hline & Usage experience & 0.03 & 0.52 & - & 1.02 \\
\hline & Age & -0.09 & $1.38^{*}$ & 0.01 & 1.12 \\
\hline & Account holder & 0.04 & 0.61 & - & 1.11 \\
\hline & Performance expectancy & 0.15 & $1.45^{*}$ & 0.02 & 2.23 \\
\hline & Effort expectancy & 0.38 & $3.68^{* * * *}$ & 0.11 & 2.06 \\
\hline & Perceived risk: & -0.10 & $1.51^{*}$ & 0.02 & 1.11 \\
\hline & Effort expectancy $x$ Perceived risk & 0.20 & $2.90^{* *}$ & 0.07 & 1.18 \\
\hline Adoption intention & Gender & -0.09 & $1.49^{*}$ & 0.01 & 1.05 \\
\hline \multirow[t]{9}{*}{$\mathrm{R}^{2}=0.52$} & Education & 0.04 & 0.85 & - & 1.11 \\
\hline & Usage experience & 0.01 & 0.12 & - & 1.02 \\
\hline & Age & 0.03 & 0.61 & - & 1.24 \\
\hline & Account holder & -0.01 & 0.09 & - & 1.11 \\
\hline & Performance expectancy & 0.11 & 1.19 & 0.01 & 2.27 \\
\hline & Effort expectancy & 0.33 & $4.53^{* * * *}$ & 0.10 & 2.29 \\
\hline & Attitude & 0.34 & $5.48 * *$ & 0.15 & 1.61 \\
\hline & Perceived risk & -0.06 & 0.93 & 0.01 & 1.13 \\
\hline & Effort expectancy $x$ Perceived risk & 0.08 & $1.33^{*}$ & 0.01 & 1.27 \\
\hline
\end{tabular}

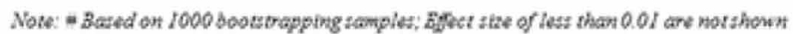

$\cdots p<0.001, \cdots p<0.05$ (mo-talled). "p<0.10 (one-tatied)

ATT, and INT. However, the role of risk remains unclear due to its weak and insignificant effects on both ATT and INT, respectively. Notably, further tests through moderation were explored to uncover whether PR and EE interact to influence the m-banking adoption process. We found support for the moderation role of PR between EE and PE (H7a: $\beta=0.11, p<0.05)$, ATT (H7b: $\beta=0.20, p<0.05$ ), and INT (H7c: $\beta=0.08, \mathrm{p}<0.10)$. Figures 3 , 4, and 5 show a simple slop graphical representation of the moderating role of PR. At high levels of risk, EE enhance PE (see Figure 3), ATT (Figure 4) and INT (Figure 5). Despite the danger posed by risk in the pre-adoption process, the ability to easily use the service has impact on consumers' attitude, their perception of the usefulness of the service and consequently on their intention to adopt the service. 
Figure 3. Simple slope: Perceived risk as moderator between effort expectancy and performance expectancy

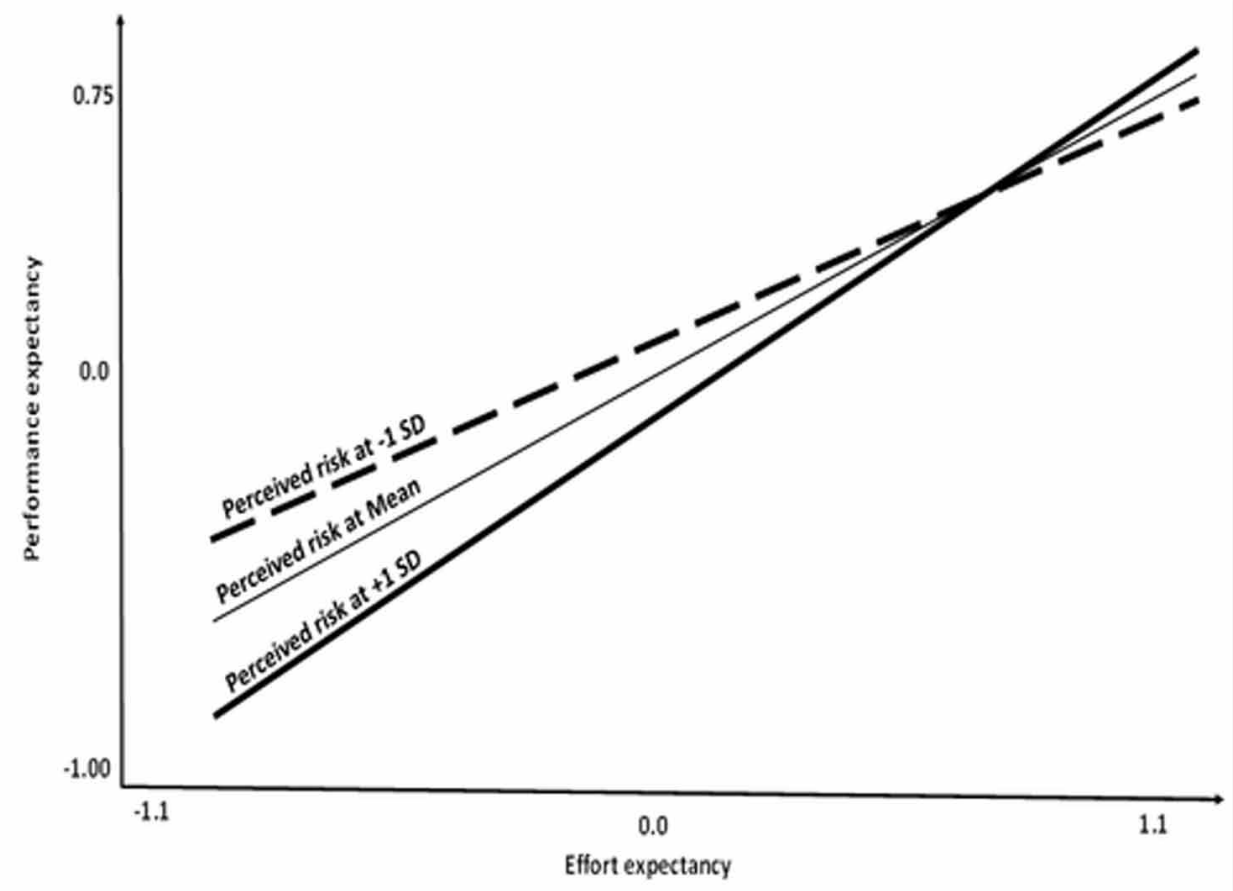

Figure 4. Simple slope: Perceived risk as moderator between effort expectancy and attitude

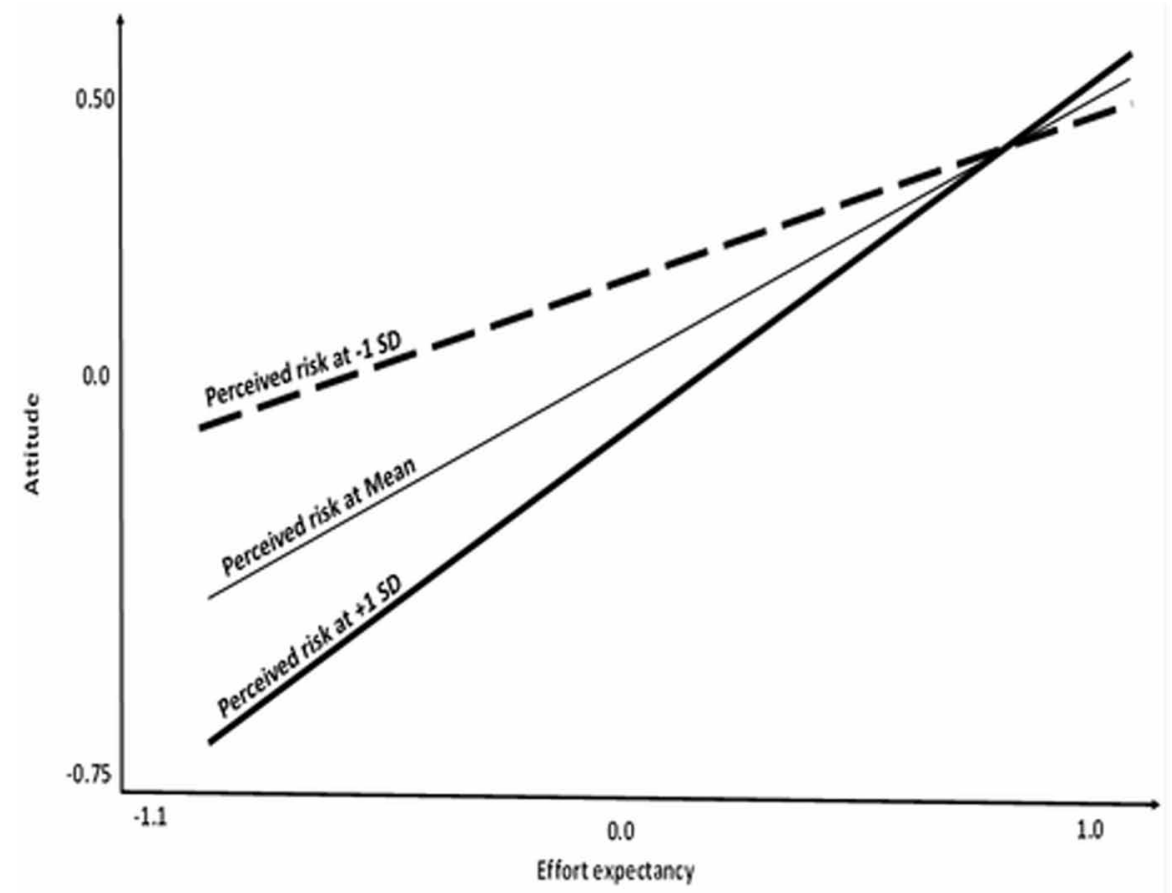


Figure 5. Simple slope: Perceived risk as moderator between effort expectancy and adoption intention

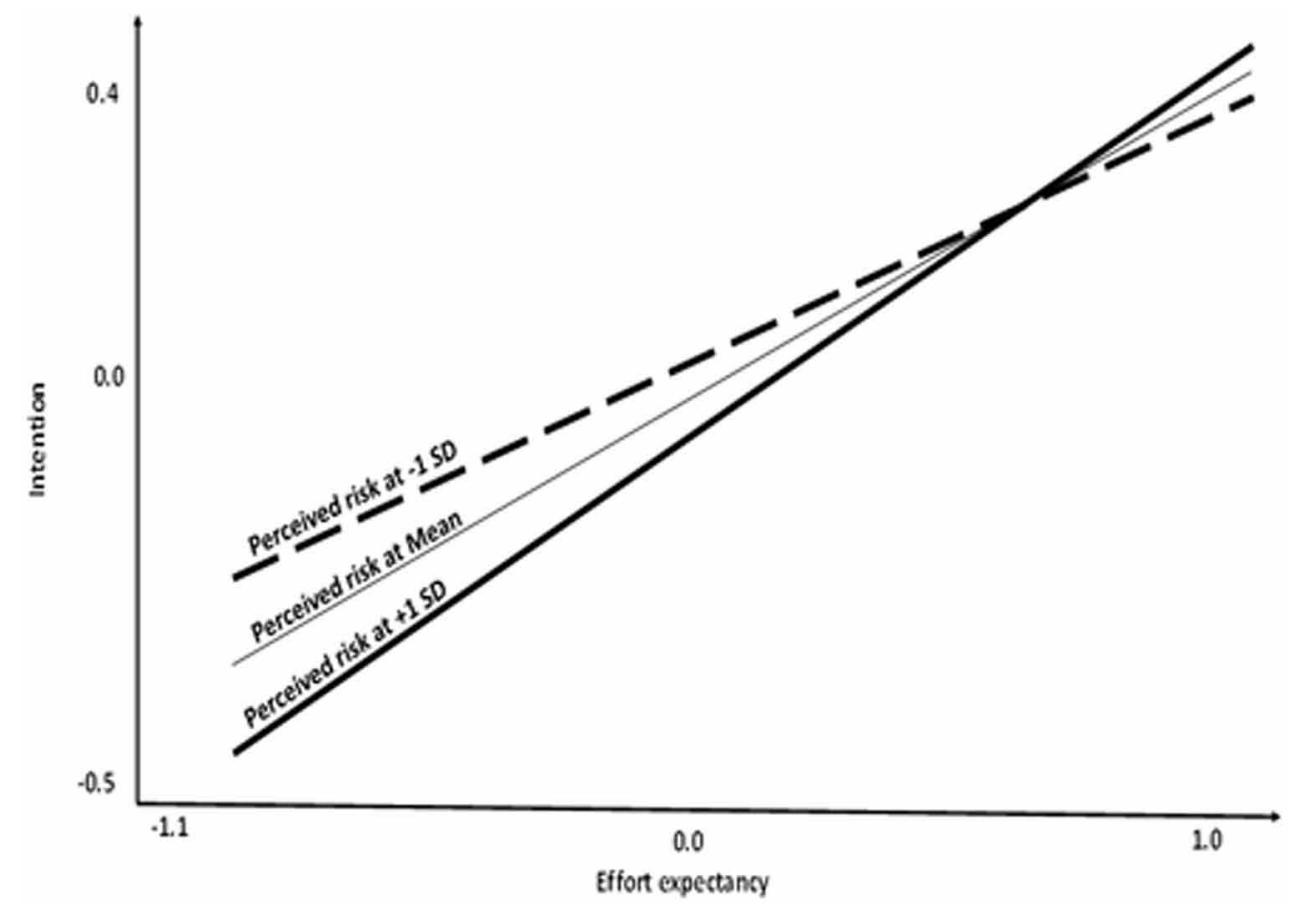

\section{DISCUSSIONS AND IMPLICATIONS}

Nine hypothetical relationships, which were based on a sample of 189 responses, were developed and examined. More importantly, the role of EE as a strong driver of PE $\left(\beta=0.66, f^{2}=0.89\right)$, ATT $\left(\beta=0.38, f^{2}=0.11\right)$, and adoption INT $\left(\beta=0.33, f^{2}=0.10\right)$ as well as its significant interaction with PR highlighted the unique role that EE plays in the innovation adoption process.

\section{Non-Significant and Weak Hypothetical Relationships}

This study found no significant direct relationship between PE and adoption INT (H1). However, earlier research by Lu et al. (2005) found a significant positive relationship between PE and INT to adopt mobile Internet services in the USA. Similarly, Yu (2012) empirically demonstrated that, the greater the PE, the greater was the individual INT to use m-banking in Taiwan.

For consumers in Pakistan, the effects of PR on their ATT and adoption INT were not of vital importance when considering $\mathrm{m}$-banking services, which implies that increasing risk in m-banking services will not deter potential consumers from adopting m-banking. This finding contrasts with previous research (Chen, 2008; Chen, 2013; Tan \& Teo, 2000), which implied that bank customers largely perceive risk as a major impediment to the adoption of m-banking services. Conversely, our finding correlated with the finding recorded by Karjaluoto et al. (2014), which implied that bank customers perceive little risk related to mobile devices and applications, and their perception of risk may have little to do with intention.

In our pre-adoption situation, it was expected that the people who were either unfamiliar or who had little previous experience with digital services, such as m-banking, might not understand the significance of PR; hence, the effect of PR on both ATT and adoption INT was insignificant. Nonetheless, the increasing awareness of growing risks and security threats on digital channels may change the perceptions and attitudes of consumers in developing countries; therefore, this finding 
may not be considered as conclusive. Banking companies in Pakistan should continually alleviate PR perceptions among both present and potential consumers and establish trust on emerging and new banking channels to facilitate their adoption and prolonged use because PR is a key aspect of consumer behavior.

Unlike H1, we found a significant but weak direct relationship between PE and ATT in support of $\mathrm{H} 2$. This relationship implies that, with increasing usefulness of m-banking services, consumer attitudes toward its adoption will increase. This finding complements previous research on m-banking, where Liang (2016) reported that the antecedents PE, EE, and facilitating conditions are strongly related to customers' attitudes toward use and intention to use m-banking services. In addition, because antecedent PE is akin to antecedent perceived usefulness, Aboelmaged and Gebba (2013) found a significant relationship between perceived usefulness and consumer ATT in m-banking services' adoption in the United Arab Emirates.

Although we did not hypothesize the association between the demographic variables and the endogenous variables (INT, ATT, PE, and EE), we found significant but weak associations between some of the demographic and endogenous variables. For example, ATT $(\beta=0.07, \mathrm{t}=1.28, \mathrm{p}<0.10$, one-tailed) and adoption INT ( $\beta=-0.09, \mathrm{t}=1.49, \mathrm{p}<0.10$, one-tailed) were found to be influenced by gender. Age had a negative effect on ATT $(\beta=-0.09, \mathrm{t}=1.38, \mathrm{p}<0.10$, one-tailed), while level of education had a positive influence on $\mathrm{EE}(\beta=0.09, \mathrm{t}=1.28, \mathrm{p}<0.10$, one-tailed $)$ and $\mathrm{PE}(\beta=0.13$, $\mathrm{t}=2.85, \mathrm{p}<0.05$, two-tailed).

\section{Significant Hypothetical Relationships}

A significant direct relationship between EE and PE (H3) was found. This finding correlates with the UTAUT, which states that EE positively affects PE (Venkatesh et al., 2003; Zhou et al., 2010). Other significant relationships were found between EE and ATT (H4) and EE and adoption INT (H5). This means that the ease of use of m-banking services is significant to both the successful implementation and user adoption of these services by a wider population. This positive relationship has been validated in many studies, irrespective of the demographic location. Nonetheless, Afshan and Sharif (2016) did not find a significant relationship between PE and intention and EE and intention in mobile banking adoption in Pakistan.

Lin (2011) found similar relationships and reported that perceived relative advantage, ease of use (effort expectancy), compatibility, competence, and integrity significantly influence ATT, which in turn leads to behavioral INT to adopt m-banking services. In another study, PE and EE were found to be the main determinants of behavioral INT in using m-banking services in Finland (Carlsson et al., 2006; Zhou et al., 2010). Moreover, previous research (Park et al., 2007) has argued that EE (ease of use) has been found to be a significant factor during the earlier stages of technology adoption, and people with lower education levels are anticipated to be more sensitive to the perceived ease of use of a service because it presents a sort of barrier to them (Szajna, 1996; Venkatesh \& Morris, 2000).

Another significant direct relationship was found between ATT and adoption INT (H6). In the context of digital banking, several previous studies have reported a positive significant relationship between ATT and INT. For instance, Suh and Han (2003) found that ATT toward using Internet banking had a significant impact on behavioral INT. Lee (2009) found the INT to use online banking to be positively affected by ATT. In the context of m-banking services, Püschel et al. (2010) found a significant positive relationship between ATT and INT. Of much importance is the significant contingent effect of perceived risk in the combined UTAUT and TPB model understudy. Thus, under conditions of high risk, the ease of use (EE) of m-banking as an innovative service reduces the negative perception of the risky nature of the service. From Tables 6 and 7 the interaction between $\mathrm{EE}$ and PR (effort expectancy $\mathrm{x}$ perceived risk) shows a positive effect on the endogenous variable (PE, ATT and INT). 
Effort expectancy plays a unique role in the adoption of innovative banking services in a developing country context: It is the strongest predictor of how adopters/users perceive the usefulness of the service and its quality/performance expectations. EE also serves as a prelude to why would-be users may decide to adopt a favorable ATT toward the service and/or adopt it. Finally, in the face of increasing threats to the adoption of innovative technology and services posed by risk (although no significant association between PR and ATT was found in the present study), the fact that consumers in developing countries find it easy to use the service dampens the threat of risk. Alternatively, the idea of risk is linked with EE such that, if consumers have problems or difficulty in using the service (probably because of its complexity), increasing levels of risk perception may lead to unfavorable attitudes toward the service and eventually lead to a reduction in adoption rates.

\section{Theoretical and Managerial Implications}

In terms of research/theoretical contributions, first, this study broadens the understanding of user adoption of m-banking services in a developing country context. Second, this study developed a theoretical model that examined the direct effects of PE and EE as well as the moderating effect of PR using variance-based analytical techniques. The model should provide a useful conceptual understanding for the testing of similar or modified frameworks to enhance our understanding of the interrelationships between the constructs identified in this study (UTAUT and TPB key constructs and the moderator, perceived risk).

Third, this paper found a significant but weak negative effect of PR on ATT and an insignificant effect on INT in a developing country, which verified the need for further research, especially in the context of technology adoption, such as in the Internet, mobile money, and m-banking contexts.

Fourth, the moderating role of PR in the innovation/technology adoption process, which has often been overlooked in previous research, was highlighted by this study. The effects of EE on PE, ATT, and INT are contingent on the level of risk. Risk "enhances"' the association between EE and PE, between EE and ATT, and between EE and INT. Increased perceptions of risk, which pose a serious threat to m-banking services' adoption, can thus be counteracted by EE (ease of use) of the product/ service. The perception of risk level and how this influences ATT is conditional on the ability of the user's effort and his/her expectations of the product and/or service.

Finally, despite the threat of risk in the m-banking adoption process, a higher level of EE is an important precursor of the innovation adoption process. This leads to our contribution in terms of the EE-PR contingency model, which was empirically tested in this paper and yet requires further validation. Thus, the inconclusiveness of the extant literature on the effect of risk in the adoption process can better be explained by the EE-PR contingency model.

Among the managerial implications, first, this study provides valuable insight for both bank executives and marketing professionals into consumers' attitudes and intentions toward the adoption of m-banking services, especially when considering that m-banking technology is among very few services that are demanded by all customer segments, including the banked, underbanked, and unbanked populations.

Second, this study provides valuable input for the banking industry regarding how present and potential consumers can be attracted to a new digital banking service and technology such as $\mathrm{m}$-banking. This is very important especially in the backdrop of changing regulatory requirements that are forecasted to pose a huge challenge to the diligently regulated banking sector. For instance, the promulgation of revised Payment System Directives (known as PSD2) by the European Commission will require the banking industry to share the account holder data with the non-banking entities such as FinTech (i.e., PayPal), Social Media companies (i.e., Facebook) and so forth. This will legally allow the non-banking entities to develop and deploy the payment services and applications thereby creating huge disruption as well as challenges for the banking industry and the bank marketing executives. 
Third, in addition to these changing regulatory requirements, it is also widely believed (e.g., Nganga \& Mwachofi, 2013) that in most of the developing countries located in Aisa, Latin America, and Africa, the technology adoption climate is highly problematic, characterized by poor business, governance, and regulatory conditions, insufficient bank branch and ATM network, low educational levels, and inappropriate infrastructure. The findings of this study provided valuable guidance and input to the policy makers and bank managers in promoting as well as increasing the m-banking adoption among the masses.

Fourth, banks, including credit unions, should regard m-banking services as an additional innovative channel as well as a vehicle for generating new revenue sources. Under these circumstances, understanding consumer adoption attitudes is paramount. Fifth, to increase the adoption ratio across different consumer segments, financial institutions, including banks, credit unions, and microfinance institutions, should create comprehensive financial education and awareness programs that facilitate as well as educate consumers on how to activate, adopt, access, and use innovative banking services, such as m-banking. In a developing country with a low literacy rate, this awareness program should be a major bank marketing strategy.

Sixth, the adoption and use of innovative and more convenient banking channels, including m-banking services and technology, such as downloadable applications, in several countries will probably precipitate increased use of these services and technologies and decreased use of physical channels. Therefore, banking companies should channel their time and money toward improving digital channel security and ease of use.

Finally, practices should also incorporate demographics in the EE-PR model. An integration of demographic factors with various levels of risk perceptions can be useful in the development of consumer and potential customer risk profiles for the financial services industry. Consumers who have high-risk perceptions of services pose a challenge to the adoption of new processes and must therefore be appropriately segmented, targeted, and assisted.

\section{Limitations and Future Research Directions}

The current study has certain limitations; therefore, interpretation of the findings should not be done without consideration for these limitations as well as the context. M-banking has become an important channel for the delivery of financial services to the unbanked, underbanked, and previously neglected customer segments, such as those at the base of the pyramid. The adoption of m-banking services in developing/emerging economies is relatively new to information systems (IS) researchers. This paper seeks to instigate further studies in contexts other than the one explored here: $\mathrm{m}$-banking. For instance, more studies are required in the broader context of mobile payments, which is considered a close variant of m-banking and have recently been quite popular in developed markets. Research targeted toward the so-called "bottom of the pyramid" consumers would also help elucidate how mobile payments stimulate financial inclusion and economic activities in emerging markets and, therefore, recommended.

Further research in the area of m-banking could employ longitudinal studies to explore the dynamics of m-banking adoption in these contexts. The goal of this paper was not to generalize its findings due to the use of a single country context and a limited sample size, which primarily included students (61\%). Further studies that use multiple country contexts and large representative samples will further enhance our understanding of $\mathrm{m}$-banking in emerging markets.

Regarding the research methodology, traditional survey methodology has been used widely in previous studies (e.g., Oliveira et al., 2016; Shaikh \& Karjaluoto, 2015) to examine both m-banking service adoption and usage. However, this type of survey methodology is considered weak when it comes to establishing causal relationships among the variables. Therefore, future research may consider the use of other research methodologies, such as experiments, to examine the direction of causal effects among the key variables in the context of m-banking adoption (Hepola et al., 2016). 
In addition to smartphones, wearables, such as smart watches, are considered a technology trend that will change the mobile world in the next few years because consumers' recognition of smartwatches is increasing (Jung et al., 2016). Hence, future research must examine the influence that these wearables exert on consumer attitudes and behaviors when adopting and using the devices to conduct tangible transactions and as a notification tool. 


\section{REFERENCES}

Aboelmaged, M., \& Gebba, T. R. (2013). Mobile banking adoption: An examination of technology acceptance model and theory of planned behavior. International Journal of Business Research and Development, 2(1), 35-50. doi:10.24102/ijbrd.v2i1.263

Afshan, S., \& Sharif, A. (2016). Acceptance of mobile banking framework in Pakistan. Telematics and Informatics, 33(2), 370-387. doi:10.1016/j.tele.2015.09.005

Ahmed, A., Rehman, U., Rizwan, M., Rafiq, M. Q., Nawaz, M., \& Mumtaz, A. (2013). Moderating Role of Perceived Risk and Innovativeness between Online Shopping Attitude and Intention. Journal of Basic and Applied Scientific Research, 3(11), 310-323.

Ajzen, I. (1985). From intentions to actions: A theory of planned behavior. In J. Kuhl \& J. Beckmann (Eds.), Action-control: From cognition to behavior (pp. 11-39). Heidelberg: Springer. doi:10.1007/978-3-642-69746-3_2

Ajzen, I. (1991). The theory of planned behavior. Organizational Behavior and Human Decision Processes, 50(2), 179-211. doi:10.1016/0749-5978(91)90020-T

Akturan, U., \& Tezcan, N. (2012). Mobile banking adoption of the youth market: Perceptions and intentions. Marketing Intelligence \& Planning, 30(4), 444-459. doi:10.1108/02634501211231928

Al-Jabri, I. M., \& Sohail, M. S. (2012). Mobile banking adoption: Application of diffusion of innovation theory. Journal of Electronic Commerce Research, 13(4), 379-391.

Alalwan, A. A., Dwivedi, Y. K., \& Rana, N. P. (2017). Factors influencing adoption of mobile banking by Jordanian bank customers: Extending UTAUT2 with trust. International Journal of Information Management, 37(3), 99-110. doi:10.1016/j.ijinfomgt.2017.01.002

Barclays, D., Thompson, R., \& Higgins, C. (1995). The partial least squares (PLS) approach to causal modeling: Personal computer adoption and use as an illustration. Technology Studies, 2(2), 285-309.

Bhattacherjee, A., \& Sanford, C. (2006). Influence Processes for Information Technology Acceptance: An Elaboration Likelihood Model. Management Information Systems Quarterly, 30(4), 805-825. doi: $10.2307 / 25148755$

Boor, P. V. D., Oliveira, P., \& Veloso, F. (2014). Users as innovators in developing countries: The global sources of innovation and diffusion in mobile banking services. Research Policy, 43(9), 1594-1607. doi:10.1016/j. respol.2014.05.003

Carlsson, C., Carlsson, J., Hyvonen, K., Puhakainen, J., \& Walden, P. (2006). Adoption of mobile devices/ services-Searching for answers with the UTAUT. In Proceedings of the 39th Hawaii International Conference on System Sciences Proceedings. IEEE.

Chang, S. J., Van Witteloostuijn, A., \& Eden, L. (2010). From the editors: Common method variance in international business research. Journal of International Business Studies, 41(2), 178-184.

Chawla, D., Chawla, D., Joshi, H., \& Joshi, H. (2017). Consumer perspectives about mobile banking adoption in India-a cluster analysis. International Journal of Bank Marketing, 35(4), 616-636. doi:10.1108/IJBM-032016-0037

Cheah, C. M., Teo, A. C., Sim, J. J., Oon, K. H., \& Tan, B. I. (2011). Factors affecting Malaysian mobile banking adoption: An empirical analysis. International Journal of Network and Mobile Technologies, 2(3), 149-160.

Chen, C. (2013). Perceived risk, usage frequency of mobile banking services. Managing Service Quality: An International Journal, 23(5), 410-436. doi:10.1108/MSQ-10-2012-0137

Chen, L. (2008). A model of consumer acceptance of mobile payment. International Journal of Mobile Communications, 6(1), 32-52. doi:10.1504/IJMC.2008.015997

Cheng, T., Lama, D., \& Yeung, A. (2006). Adoption of internet banking: An empirical study in Hong Kong. Decision Support Systems, 42(3), 1558-1572. doi:10.1016/j.dss.2006.01.002

Chin, W., \& Newsted, P. R. (1999). Structural equation modeling analysis with small samples using partial least squares. In R. Hoyle (Ed.), Statistical strategies for small sample research (pp. 307-341), Thousand Oak: Sage. 
Crabbe, M., Standing, C., Standing, S., \& Karjaluoto, H. (2009). An adoption model for mobile banking in Ghana. International Journal of Mobile Communications, 7(5), 515-543. doi:10.1504/IJMC.2009.024391

Cruz, P., Barretto Filgueiras Neto, L., Muñoz-Gallego, P., \& Laukkanen, T. (2010). Mobile banking rollout in emerging markets: Evidence from Brazil. International Journal of Bank Marketing, 28(5), 342-371. doi:10.1108/02652321011064881

Davis, F. D. (1989). Perceived usefulness, perceived ease of use, and user acceptance of information technology. Management Information Systems Quarterly, 12(3), 319-340. doi:10.2307/249008

Falk, R. F., \& Miller, N. B. (1992). A primer for soft modeling. Ohio: The University of Akron Press.

Fornell, C., \& Larcker, D. F. (1981). Evaluating structural equation models with unobservable variables and measurement error. JMR, Journal of Marketing Research, 18(1), 39-50. doi:10.2307/3151312

Hair, J. F., Anderson, R. E., Tatham, R. L., \& Black, W. C. (1998). Multivariate data analysis (5th ed.). London: Prentice Hall International.

Hair, J. F., Hult, G. T. M., Ringle, C. M., \& Sarstedt, M. (2017). A primer on partial least squares structural equation modeling (PLS-SEM) (2nd ed.). Sage Publications, Inc.

Hanafizadeh, P., Behboudi, M., Koshksaray, A. A., \& Tabar, M. J. S. (2014). Mobile-banking adoption by Iranian bank clients. Telematics and Informatics, 31(1), 62-78. doi:10.1016/j.tele.2012.11.001

Harman, H. H. (1976). Modern factor analysis (3rd ed.). Chicago: The University of Chicago.

Hepola, J., Karjaluoto, H., \& Shaikh, A. A. (2016). Consumer Engagement and Behavioral Intention Toward Continuous Use of Innovative Mobile Banking Applications-A Case Study of Finland. In Proceedings of the International Conference on Information Systems (ICIS-2016), Dublin, Ireland, December 11-14.

Hung, S. Y., Ku, C. Y., \& Chang, C. M. (2003). Critical factors of WAP services adoption: An empirical study. Electronic Commerce Research and Applications, 2(1), 42-60. doi:10.1016/S1567-4223(03)00008-5

Im, I., Kim, Y., \& Han, H. J. (2008). The effects of perceived risk and technology type on users' acceptance of technologies. Information \& Management, 45(1), 1-9. doi:10.1016/j.im.2007.03.005

Jung, Y., Kim, S., \& Choi, B. (2016). Consumer valuation of the wearables: The case of smartwatches. Computers in Human Behavior, 63, 899-905. doi:10.1016/j.chb.2016.06.040

Karjaluoto, H., Töllinen, A., Pirttiniemi, J., \& Jayawardhena, C. (2014). Intention to use mobile customer relationship management systems. Industrial Management \& Data Systems, 114(6), 966-978. doi:10.1108/ IMDS-11-2013-0480

Kemery, E. R., \& Dunlap, W. P. (1986). Partialling factor scores does not control method variance: A reply to Podsakoff and Tordor. Journal of Management, 12(4), 535-544. doi:10.1177/014920638601200407

Kim, D. J., Ferrin, D. L., \& Rao, H. R. (2008). A trust-based consumer decision-making model in electronic commerce: The role of trust, perceived risk, and their antecedents. Decision Support Systems, 44(2), 544-564. doi:10.1016/j.dss.2007.07.001

Kim, G., Shin, B., \& Lee, H. G. (2009). Understanding dynamics between initial trust and usage intentions of mobile banking. Information Systems Journal, 19(3), 283-311. doi:10.1111/j.1365-2575.2007.00269.x

Kuo, Y. F., \& Yen, S. N. (2009). Towards an understanding of the behavioral intention to use 3G mobile valueadded services. Computers in Human Behavior, 25(1), 103-110. doi:10.1016/j.chb.2008.07.007

Lee, M. C. (2009). Factors influencing the adoption of internet banking: An integration of TAM and TPB with perceived risk and perceived benefit. Electronic Commerce Research and Applications, 8(3), 130-141. doi:10.1016/j.elerap.2008.11.006

Liang, C. C. (2016). Subjective Norms and Customer Adoption of Mobile Banking: Taiwan and Vietnam. In Proceedings of the 49th Hawaii International Conference on System Sciences Proceedings (pp. 1577-1585). IEEE. doi:10.1109/HICSS.2016.199 
Liang, H., Saraf, N., Hu, Q., \& Xue, Y. (2007). Assimilation of enterprise systems: The effect of institutional pressures and the mediating role of top management. Management Information Systems Quarterly, 31(1), 59-87. doi: $10.2307 / 25148781$

Liao, C. H., Tsou, C. W., \& Huang, M. F. (2007). Factors influencing the usage of 3G mobile services in Taiwan. Online Information Review, 31(6), 759-774. doi:10.1108/14684520710841757

Lin, H. F. (2011). An empirical investigation of mobile banking adoption: The effect of innovation attributes and knowledge-based trust. International Journal of Information Management, 31(3), 252-260. doi:10.1016/j. ijinfomgt.2010.07.006

Lin, W. B. (2008). Investigation on the model of consumers' perceived risk-integrated viewpoint. Expert Systems with Applications, 34(2), 977-988. doi:10.1016/j.eswa.2006.10.042

Lu, J., Yao, J. E., \& Yu, C. S. (2005). Personal innovativeness, social influences and adoption of wireless Internet services via mobile technology. The Journal of Strategic Information Systems, 14(3), 245-268. doi:10.1016/j. jsis.2005.07.003

Luarn, P., \& Lin, H. H. (2005). Toward an understanding of the behavioral intention to use mobile banking. Computers in Human Behavior, 21(6), 873-891. doi:10.1016/j.chb.2004.03.003

Luo, X., Li, H., Zhang, J., \& Shim, J. P. (2010). Examining multi-dimensional trust and multi-faceted risk in initial acceptance of emerging technologies: An empirical study of mobile banking services. Decision Support Systems, 49(2), 222-234. doi:10.1016/j.dss.2010.02.008

Martin, A., Lakshmi, T. M., \& Venkatesan, V. P. (2014). An information delivery model for banking business. International Journal of Information Management, 34(2), 139-150.

Masrek, M. N., Mohamed, I. S., Daud, N. M., \& Omar, N. (2014). Technology trust and mobile banking satisfaction: A case of Malaysian consumers. Procedia: Social and Behavioral Sciences, 129, 53-58. doi:10.1016/j.sbspro.2014.03.647

Mehrad, D., \& Mohammadi, S. (2016). Word of Mouth impact on the adoption of mobile banking in Iran. Telematics and Informatics.

Mehrad, D., \& Mohammadi, S. (2016). Word of Mouth impact on the adoption of mobile banking in Iran. Telematics and Informatics, 34(7), 1351-1363. doi:10.1016/j.tele.2016.08.009

Miltgen, C. L. (2013). Determinants of end-user acceptance of biometrics: Integrating the Big 3 of technology acceptance with privacy context. Decision Support Systems, 56, 103-114. doi:10.1016/j.dss.2013.05.010

Mitra, A., \& Mitra, A. (2016). Effect of information content and form on customers' attitude and transaction intention in mobile banking: Moderating role of perceived privacy concern. International Journal of Bank Marketing, 34(7), 1092-1113. doi:10.1108/IJBM-07-2015-0107

Moser, F. (2015). Mobile banking: A fashionable concept or an institutionalized channel in future retail banking? Analyzing patterns in the practical and academic mobile banking literature. International Journal of Bank Marketing, 33(2), 162-177. doi:10.1108/IJBM-08-2013-0082

Nganga, S. I., \& Mwachofi, M. M. (2013). Technology Adoption and the Banking Agency in Rural Kenya. Journal of Sociological Research, 4(1), 249-266.

Oh, S., Lehto, X. Y., \& Park, J. (2009). Travelers' intent to use mobile technologies as a function of effort and performance expectancy. Journal of Hospitality Marketing \& Management, 18(8), 765-781. doi:10.1080/19368620903235795

Oliveira, T., Faria, M., Thomas, M. A., \& Popovič, A. (2014). Extending the understanding of mobile banking adoption: When UTAUT meets TTF and ITM. International Journal of Information Management, 34(5), 689-703. doi:10.1016/j.ijinfomgt.2014.06.004

Oliveira, T., Thomas, M., Baptista, G., \& Campos, F. (2016). Mobile payment: Understanding the determinants of customer adoption and intention to recommend the technology. Computers in Human Behavior, 61, 404-414. doi:10.1016/j.chb.2016.03.030 
Pakistan Telecommunication Authority. (2016). Annual Cellular Subscribers. Retrieved from http://www.pta. gov.pk/index.php?Itemid=599

Park, J., Yang, S., \& Lehto, X. (2007). Adoption of mobile technologies for Chinese consumers. Journal of Electronic Commerce Research, 8(3), 196-206.

Payment Systems Review. (2016). Retrieved from http://www.sbp.org.pk/PS/PDF/FiscalYear-2015-16.pdf

Podsakoff, N. P., \& Organ, D. W. (1986). Self-reports in organizational research: Problems and prospects. Journal of Management, 12(4), 531-544. doi:10.1177/014920638601200408

Podsakoff, P. M., MacKenzie, S. B., Lee, J. Y., \& Podsakoff, N. P. (2003). Common method biases in behavioral research: A critical review of the literature and recommended remedies. The Journal of Applied Psychology, 88(5), 879-903. doi:10.1037/0021-9010.88.5.879 PMID:14516251

Püschel, J., Afonso Mazzon, J., Mauro, C., \& Hernandez, J. (2010). Mobile banking: Proposition of an integrated adoption intention framework. International Journal of Bank Marketing, 28(5), 389-409. doi:10.1108/02652321011064908

Ratten, V. (2013). Social cognitive theory in mobile banking innovations. International Journal of E-Business Research, 7(1), 39-51. doi:10.4018/jebr.2011010103

Riffai, M. M. M. A., Grant, K., \& Edgar, D. (2012). Big TAM in Oman: Exploring the promise of on-line banking, its adoption by customers and the challenges of banking in Oman. International Journal of Information Management, 32(3), 239-250. doi:10.1016/j.jinfomgt.2011.11.007

Ringle, C. M., Wende, S., \& Becker, J.-M. (2015). SmartPLS 3. Bönningstedt: SmartPLS. Retrieved from http:// www.smartpls.com

Riquelme, H. E., \& Rios, R. E. (2010). The moderating effect of gender in the adoption of mobile banking. International Journal of Bank Marketing, 28(5), 328-341. doi:10.1108/02652321011064872

Shaikh, A. A. (2016). Examining consumers' intention, behavior, and beliefs in mobile banking adoption and continuous usage. Jyväskylä studies in business and economics, 172.

Shaikh, A. A., \& Karjaluoto, H. (2015). Mobile banking adoption: A literature review. Telematics and Informatics, 32(1), 129-142. doi:10.1016/j.tele.2014.05.003

Shaikh, A. A., \& Karjaluoto, H. (2016a). Mobile banking services continuous usage--case study of Finland. In Proceedings of the 49th Hawaii International Conference on System Sciences Proceedings (pp. 1497-1506). IEEE.

Shaikh, A. A., \& Karjaluoto, H. (2016b). On Some Misconceptions Concerning Digital Banking And Alternative Delivery Channels. International Journal of E-Business Research, 12(3), 1-16. doi:10.4018/IJEBR.2016070101

Shen, C. C., \& Chiou, J. S. (2010). The impact of perceived ease of use on Internet service adoption: The moderating effects of temporal distance and perceived risk. Computers in Human Behavior, 26(1), 42-50. doi:10.1016/j.chb.2009.07.003

Simon, M. K. (2011). Dissertation and Scholarly Research: Recipes for Success (2011 ed.). Seattle, WA: Dissertation Success, LLC. Retrieved from http://dissertationrecipes.com

Suh, B., \& Han, I. (2003). Effect of trust on customer acceptance of Internet banking. Electronic Commerce Research and Applications, 1(3), 247-263.

Sylvie, L., \& Xiaoyan, L. (2005). Consumers' attitudes towards online and mobile banking in China. International Journal of Bank Marketing, 23(5), 362-380. doi:10.1108/02652320510629250

Szajna, B. (1996). Empirical Evaluation of the Revised Technology Acceptance Model. Management Science, 42(1), 85-92. doi:10.1287/mnsc.42.1.85

Tan, M., \& Teo, T. S. H. (2000). Factors influencing the adoption of internet banking. Journal of the Association for Information Systems, 1(5), 1-44.

Teo, T. S. H., \& Pok, S. H. (2003). Adoption of WAP-enabled mobile phones among internet user. Omega, 31(6), 483-498. doi:10.1016/j.omega.2003.08.005 
Thakur, R., \& Srivastava, M. (2014). Adoption readiness, personal innovativeness, perceived risk and usage intention across customer groups for mobile payment services in India. Internet Research, 24(3), 369-392. doi:10.1108/IntR-12-2012-0244

Varshney, U., \& Vetter, R. (2001, January). A framework for the emerging mobile commerce applications. In Proceedings of the 34th Annual Hawaii International Conference on System Sciences, 2001. IEEE. doi:10.1109/ HICSS.2001.927208

Venkatesh, V., \& Morris, M. G. (2000). Why don't men ever stop to ask for directions? Gender, social influence, and their role in technology acceptance and usage behavior. Management Information Systems Quarterly, 24(1), 115-139. doi:10.2307/3250981

Venkatesh, V., Morris, M. G., Davis, G. B., \& Davis, F. D. (2003). User acceptance of information technology: Toward a unified view. Management Information Systems Quarterly, 27(3), 425-478. doi:10.2307/30036540

World Bank. (2016). What Will It Take for Pakistan to Achieve Financial Inclusion? Retrieved from http:// www.worldbank.org/en/news/feature/2016/02/08/what-will-it-take-for-pakistan-to-achieve-financial-inclusion

Yu, C. S. (2012). Factors affecting individuals to adopt mobile banking: Empirical evidence from the UTAUT model. Journal of Electronic Commerce Research, 13(2), 104-121.

Zhou, T., Lu, Y., \& Wang, B. (2010). Integrating TTF and UTAUT to explain mobile banking user adoption. Computers in Human Behavior, 26(4), 760-767. doi:10.1016/j.chb.2010.01.013

Aijaz A. Shaikh is a University Lecturer (Marketing) at the Jyväskylä University School of Business and Economics in Finland. He earned his Ph.D. (Marketing) from the Jyväskylä University School of Business and Economics in Finland. Prior to that, he earned his M.Sc. from the AACSB-accredited Hanken School of Economics in Finland, and he has more than 16 years of professional (mostly banking), teaching, and research experience. His primary research interests include both qualitative and quantitative studies in the broader areas of Consumer Behavior, Mobile Banking, Branchless Banking, Internet Banking, Payment Systems, Social Media, and Shared Economy. He has published in Computers in Human Behavior, Telematics and Informatics, and other refereed journals, such as the International Journal of Bank Marketing, Research in International Business and Finance, Journal of Financial Services Marketing, and the International Journal of E-Business Research.

Richard Glavee-Geo holds a Ph.D. from the Molde University College, Norway. He is an Associate Professor at the Norwegian University of Science and Technology (NTNU), Aalesund campus and teaches Export Management, Marketing Research and Logistics and Supply Chain Management to undergraduate business students and International Marketing to postgraduate master students. His research interests are in the areas of B2B marketing/ inter-organizational relationships, buyer-supplier relationships, bank marketing, consumer and organizational buying behavior. His recent publications have appeared in various journals such as the International Journal of Bank Marketing, Research in International Business and Finance and so forth.

Heikki Karjaluoto is a Professor of Marketing at the University of Jyväskylä, Finland. His research interests include Electronic and Mobile Business, Customer Value and Financial Services Marketing. Previous publications have appeared in the Computers in Human Behavior, Industrial Marketing Management, Internet Research, Telecommunications Policy, among others. 